\title{
ANÁLISIS PALINOLÓGICO DE LAS ESPECIES MELITÓFI- LAS DE LA FAMILIA FABACEAE DEL CENTRO DE LA ARGENTINA. PARTE I.
}

\author{
Faricelli, M. E. ${ }^{1} ;$ Kraus, T. A. $^{1}$ \& BIANCO, C. A. $^{1}$
}

\begin{abstract}
RESUMEN
La familia Fabaceae es predominantemente entomófila y constituye la principal fuente de néctar y de polen para la abeja Apis mellifica (L.) L. Los análisis melisopalinológicos están basados en observaciones microscópicas de muestras de miel. La visualización y el reconocimiento de los granos de polen contenidos en ella proveen información referente a sus orígenes botánico y geográfico. El objetivo de este trabajo fue estudiar los caracteres palinológicos de especies de la familia Fabaceae melitófilas tanto nativas como exóticas. Los granos de polen de 21 especies pertenecientes a las subfamilias Caesalpinioideae, Mimosoideae y Papilionoideae fueron observados con microscopio óptico. Los siguientes caracteres cualitativos: forma (vista ecuatorial), AMB (vista polar), ornamentación de la exina, características de la apertura, permitieron describir comparativamente la morfología del polen de las especies analizadas. Los resultados de este estudio contribuyen al conocimiento de los granos de polen, principal fuente de alimento de las abejas melíficas en el centro de Argentina.

Palabras clave: Fabaceae, polen, melisopalinología, Argentina.
\end{abstract}

\section{SUMMARY}

\section{Palynological analysis of the melittophilous species of Fabaceae from the center of Argentina. Part I.}

The family Fabaceae is principally a bee-pollinated family and it constitutes the major source of nectar and pollen for honeybees Apis mellifica (L.) L. Melissopalynological analysis are based on microscopical observations of samples of honey. The visualization and recognition of the pollen grains contained in the honey provide information about the botanical and geographical origin of the honey. The objective of this work was to study the palynological characters of both native and exotic species of melittophilous legumes. Pollen grains of 21 species belonging to the subfamilies Caesalpinioideae, Mimosoideae and Papilionoideae were observed by using the optical microscope. The following qualitative characters: shape (ecuatorial view), AMB (polar view), ornamentation of the exine and features of the apertures, allowed to describe comparatively the pollen morphology of the analyzed species. The results of this study contribute to the knowledge of the pollen grains, the main source of food for honeybees in the center of Argentina.

Key words: Fabaceae, pollen, melissopalynology, Argentina.

1.- Facultad de Agronomía y Veterinaria. Universidad Nacional de Río Cuarto. Ruta 36, km. 601. (5800) Río Cuarto, Córdoba.

Proyecto subsidiado por la Secretaría de Ciencia y Técnica de la Universidad Nacional de Río Cuarto. Manuscrito recibido el 28 de abril de 2004 y aceptado para su publicación el 13 de octubre de 2004. 